\title{
RELAÇÕES INTERESPECÍFICAS DE CUIDADO NO SISTEMA DE SAÚDE CONVENCIONAL BRASLEIRO: UMA ANÁLISE ANTROPOLÓGICA SOBRE A DINÂMICA DA ZOOTERAPIA
}

\author{
Ivana Teixeira ${ }^{1}$
}

\section{Introdução}

Ao abordar o tema da relação interespecífica entre homem e animal como caminho para a saúde e o bem estar físico e mental humano, convém melhor definirmos $\mathrm{o}$ objeto. $\mathrm{O}$ termo zooterapia ${ }^{2}$ refere-se a toda prática terapêutica de cuidado à saúde humana que envolva um animal como coadjuvante no processo de tratamento ou cura. Nossa atenção estará voltada, então, para as atividades que contam com a participação do animal vivo em interação com um terapeuta humano e com a/as pessoas assistidas. Assim, a utilização do animal como aquele que possui propriedades terapêuticas, longe da ideia de um catálogo de substâncias animais nos remete a descobrir a participação do animal no seu inteiro, intervindo em múltiplos processos da vida, isto é, participando ativamente do controle de doenças humanas. Esta técnica é denominada no contexto das terapias com animais como Mediação Animal (Fondation Pierre\&Sommer, s/d), Petterapia Levinson, 1969), Terapia Assistida por Animais- TAA (Delta Society, s/d e, Zooterapia (Costa Neto, 2005, 2007; Martins, 2004). Embora não haja um consenso sobre a melhor expressão para nominar tais atividades, estes termos apontam para uma das bases desta técnica, a centralidade da atuação animal.

Na sua maioria, a zooterapia enquanto técnica de cuidado humano através da mediação animal se desenvolve no seio do sistema de saúde convencional ocidental. O surgimento desta atividade no interior de espaços de recuperação é um dado incerto. Ela tem sido datada do século IX, desde os registros de que os pacientes de um hospital, na cidade de Ghee, Bélgica, eram tratados por pássaros (Matuszek, 2010; Grandgeorge e

\footnotetext{
${ }^{1}$ Universidade Federal do Rio Grande do Sul, Brasil.

${ }^{2}$ Igualmente, o termo zooterapia pode designar o uso de remédios elaborados a partir de partes do corpo de animais, de produtos de seu metabolismo como secreções corporais e excrementos, ou ainda, de materiais construídos por eles como ninhos e casulos (Costa Neto, 1999; 2006; Neto, 2004). A utilização medicinal do animal, seja na forma de matéria-prima ou como 'terapeutas', tem o objetivo de tratar e prevenir doenças e enfermidades nos seres humanos. O termo zooterapia pode referir-se também à terapêutica para os animais, ou seja, às doenças que acometem os animais, Seu correlato, no campo da medicina veterinária, denomina-se etno veterinária.
} 
Hausberger, 2011). Mais adiante, no final do século XVIII, em torno de 1792, aponta-se que pássaros, gaivotas, falcões e coelhos foram usados em terapias para ajudar pessoas dementes no York Retreat, na Grâ Bretanha (Fine, 2010; Serpell, 2010). Em 1867, o Bethel Institute, em Bielefeld, Alemanha, desenvolveu programas que incluíam atividades com cães, gatos e pássaros, em um centro eqüestre. Essa medida pretendia tratar pessoas com epilepsia, inicialmente, mas foi aos poucos sendo oferecida para tratamento dos mais variados problemas físicos e mentais (Grandgeorge e Hausberger, 2011: 399). Nos Estados Unidos, a enfermeira Florence Nightingele, também um registro datado da metade do século XIX, observou que os animais domésticos eram excelentes companhias para os enfermos com patologias crônicas (Jofré, 2005; Halm, 2008) e ofereceu o primeiro registro de zooterapia em material do campo da saúde humana. A enfermeira comentou em seu livro que "a small pet is often an excelente companion for the sick, for long chronic cases especially" (Nightingale, 1860: 103) ${ }^{3}$. Em 1919, o St. Elizabeth's Hospital, em Washington, teve autorizada por Franklin Lane, a companhia de animais como parte dos cuidados oferecidos aos pacientes psiquiátricos, com o objetivo de "humanizar" o tratamento de saúde oferecido àqueles marinheiros vítimas de traumas advindos de sua participação na I Guerra Mundial (Chandler, 2005). A situação repetiu-se com os enfermos da Força Aérea americana, no ano de 1942, quando animais foram incluídos nos programas de reabilitação, através de tarefas realizadas na granja do hospital visando minimizar a monotonia do local, além dos animais servirem como alimento e reforço na execução de tarefas laborais (Chandler, 2005). Na mesma perspectiva outras Fazendas Terapêuticas foram destinadas aos soldados que regressavam da II Guerra Mundial, nos Estados Unidos (Grandgeorge e Hausberger, 2011; Serpell, 2010; Matuszek, 2010). Entretanto, foi Boris Levinson ${ }^{4}$ quem, no final dos anos 50 em Nova York, introduz a pet-terapy para o tratamento do Autismo em crianças, no contexto da clínica. Este psicólogo infantil, ao tentar estabelecer alguma interação com um paciente de 10 anos, diagnosticado com grandes problemas de socialização, percebeu que seu cão Jingles - um labrador seu

\footnotetext{
${ }^{3}$ Nightingale, F. Notes on Nursing. What it is, and what it is not. Nova Iorque, 1860.

${ }^{4}$ O Dr. Levinson, nasceu na cidade de Kalvarijah, na Lituânia, em 07 de julho de 1907, mas emigrou com sua família para os Estados Unidos vinte anos depois. Sua formação acadêmica iniciou-se no curso de Ciências e foi sendo direcionado para a Psicologia Clínica até que em 1972, já reconhecido professor universitário e terapeuta, aceitou o convite para tornar-se diretor do Human/Companion Animal Therapy, um programa desenvolvido por um centro de tratamento de crianças autistas, no Broklyn, em Nova Iorque. Por seu envolvimento com essa prática lhe foi creditado o título de primeiro profissional habilitado para "clinicar" através da companhia de animais.
} 
animal de estimação que tinha como hábito acompanhar o doutor Levinson até o consultório - havia estabelecido uma interação com o garoto de tal modo que ele até então não havia obtido (Levinson, 1969). Os trabalhos produzidos por Levinson, assim como sua postura em defesa desta terapia, chamaram a atenção da brasileira Nise da Silveira $^{5}$, que manteve contatos com Levinson. Essa psiquiatra apropriou-se de tais escritos para justificar a permanecia dos animais, e o posterior desenvolvimento da zooterapia, nas dependências do Hospital Psiquiátrico Pedro II - HFP II, na cidade do Rio de Janeiro.

Atualmente a terapia com animais é desenvolvida em diversos hospitais públicos, clínicas geriátricas e centros de atenção psico-social. Na cidade de Porto Alegre, o Centro de Atenção Psicossocial da Infância e Adolescência- CAPSi, do Hospital de Clínicas implantou um projeto de Terapia Mediada por Animais-TMA ${ }^{6}$, em encontros semanais, com 50 minutos de duração, no pátio do Capsi. De modo semelhante, no ano 2008, o Hospital Pequeno Príncipe, em Curitiba, firma um contrato com o projeto "Amigo Bicho" para que atividades mediadas por animis fossem oferecidas na ala psiquiátrica infantil, como recreação. Em São Paulo, o projeto TAC atende, desde 2009, a ala psiquiátrica e pediátrica do Hospital de Clinicas da capital paulista. Assim como o projeto Pet Terapeuta, que em 2010 começou a atividade de terapia com animais no Hospital São Pedro, em Porto Alegre.

Com a intenção de acompanhar diferentes propostas de zooterapia, esta pesquisa amparou-se em etnografia realizada junto a projetos que desenvolvem terapia assistida por animais, cujo trabalho de campo foi realizado ao longo dos anos 2011, 2012 e 2013 nas cidades de Porto Alegre, São Paulo e Rio de Janeiro. O projeto Pet Terapia ${ }^{8}$, atuante na cidade de Porto Alegre, é uma associação que desenvolve terapia com animais em hospitais, casas geriátricas e escolas especiais, através do trabalho de uma psicóloga que

\footnotetext{
${ }^{5}$ Não há dúvida de que o pensamento e a praxis Junguiana foram introduzidos no Brasil pela Dra. Nise da Silveira, no final da década de 1950. Em 1954, impressionada com a recorrência de mandalas nas pinturas de esquizofrênicos, ela escreveu ao eminente psiquiatra de Zurique, Carl Gustav Jung, comentando deste material, sendo prontamente respondida e ensejada a sua colaboração (Silveira, 1982). Isto a estimulou a apresentar no II Congresso Internacional de Psiquiatria, em Zurique (1957), uma exposição com as pinturas e modelagens dos esquizofrênicos que ocupavam as sessões de terapia ocupacional no então Centro Psiquiátrico do Rio de Janeiro (atual Hospital Pedro II).

${ }^{6} \mathrm{O}$ trabalho desenvolvido no HCPA foi proposto pela médica veterinária, mestre e doutora em psicologia Ceres Faraco, que de 2008 até meados de 2009, desenvolveu o projeto Terapia Mediada por Animais TMA, no CAPSi do hospital, este o primeiro projeto de terapia com animais em uma instituição de saúde pública da capital gaúcha.

${ }^{7}$ http://projetoamigobicho.blogspot.com.br

${ }^{8}$ http://www.petterapeuta.com.br
} 
trabalha com cães, pássaros e coelhos. No Rio de Janeiro, a pesquisa de campo foi realizada através de visitas e entrevistas junto à Associação Pelo Próximo e Associação Animallis. O Pêlo Próximo ${ }^{9}$ trabalha desenvolvendo atividades de recreação onde os animais atuam como mediadores, em escolas, clínicas geriátricas e mais recentemente em hospitais. Os terapeutas humanos são "voluntários" que desejam participar de uma atividade de benfeitoria para com o mundo, assim, junto ao seu animal de estimação fazem essas visitas que configuram-se em uma linda tarde de lazer em torno de cães e calopsitas. O trabalho da Associação Animallis ${ }^{10}$ está direcionado ao cuidado de pessoas com Mal de Alzheimer, através da interação interespecífica entre os pacientes e cães da raça Collie ou calopsitas. Na cidade de São Paulo, acompanhamos as atividades do Projeto TAC-Terapia Assistida por Cães ${ }^{11}$; essa associação desenvolve seu trabalho no interior do Instituto de Psiquiatria do Hospital das Clínicas da USP, onde o terapeuta e seus sete cães desenvolvem atividades à crianças internadas. Observamos os ateliês de Ludoterapia assistida por cães e Brincar terapêutico, dirigidos à crianças autistas e esquizofrênicas.

Com o intuito de oferecer uma contribuição analítica à discussão sobre a relação humano-animais no contexto urbano, pretendemos neste artigo centrar nossa análise para um momento preciso, o período da sessão terapêutica, isto é, o instante onde o animal atua como terapeuta. Com isso, as ações desenvolvidas antes do momento terapêutico, são aqui apresentadas por serem parte de um processo através do qual os humanos se posicionam para formular uma solicitação de ajuda aos não-humanos. Neste sentido, o objetivo de nosso trabalho é, pois, mostrar como o estatuto do animal terapeuta está relacionado com o fruto que a troca de ações oferecerá e, como isso resulta em determinado tipo de relação estabelecida com o animal, sobretudo levando-se em consideração o tipo de atividade que se espera dele. Por conseguinte, a análise do que é solicitado a este animal e a contrapartida humana durante a sessão de zooterapia nos parece ser um meio adequado para chegar a entender as concepções subjacentes de humano e de animal- que dão sentido às práticas terapêuticas.

\footnotetext{
${ }^{9}$ http://www.peloproximo.com.br

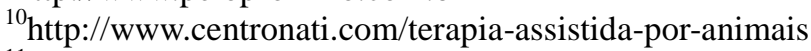

${ }^{11} \mathrm{http}: / /$ tac.org.br
} 
As abordagens sobre as quais nos apoiamos para analisar os dados desta pesquisa, embora contem com suas especificidades teórico-metodológicas imanentes das etnografias destes trabalhos - diga-se em especial as etnografias do leste europeu (Haudricourt, 1962; Ferret, 2012, 2014), da mesoamérica (Pitrou, 2011,2012, 2014) e do círculo polar ártico (Ingold) - permitem colher elementos para análises e reflexões acerca dos modos de composição do social que incluam humanos e não humanos como sujeitos dotados de intencionalidade e agência. Nossa discussão parte dos estudos que convergem para uma antropologia da técnica, como os célebres trabalhos de AndréGeorge Haudricourt (1962) e Carole Ferret (2012), cujas abordagens centraram-se na observação de ações desenvolvidas pelo homem em direção à natureza (criação de animais), que nos inspiraram para realizar uma categorização das ações dos terapeutas (humanos) de zooterapia em direção ao animal da zooterapia. Esse trabalho foi feito levando-se em consideração todos os procedimentos que visam aproximar o animal do ambiente da saúde e dos usuários, desde a origem do animal, ao adestramento de comandos básicos e cuidados veterinários exigidos pelo Departamento de Zoonoses dos estabelecimentos de saúde.

Para além de ações humanas em direção aos animais, gostaríamos de dar luz a uma técnica que conjuga a coordenação de ações executadas por espécies diferentes, envolvidos numa produção conjunta. Perig Pitrou (2011, 2012), propõe pensar o entendimento de vida como a relação entre forma e processo através do qual seres não humanos sejam imbricados em práticas, tais como processos de cura, crescimento, nascimento ou morte. Nesta perspectiva esses seres são tomados como agentes na produção de uma cadeia de signados através do qual operam as atividades esperadas destes não humanos (Pitrou, 2011, 2014). Tomando como objeto analítico os rituais religiosos do povo Mixe da serra norte de Oaxaca no México, Pitrou propõe considerar a oferenda (depositário) como um modo de figuração dos processos vitais que são solicitados pelos Mixe à entidade nomeada “Aquele que faz viver". Os não-humanos de Pitrou são artefatos com estatuto de entidade que constitui uma instância capaz de favorecer os processos vitais (Pitrou, 2014).

Essas orientações permitiram, para além de categorizar atividades dos homens em direção dos animais, objetivar as atividades executadas pelos animais em interação com os humanos (pacientes ou terapeutas) para pensar como se concebe a zooterapia e, tentar clarear as relações que prevalecem no contexto estudado. Nessa perspectiva, o 
método adotado consiste, pois, em ao invés de sumarizar o que se diz sobre o animal terapeuta, estudar as circunstâncias em que as pessoas se dirigem a ele e vice-versa.

\section{A zooterapia como técnica interespecífica de cuidado}

As relações com o animal na terapia se estabelecem em uma sequência de procedimentos dentro dos quais se integram uma série de operações preparatórias. Esquematicamente algumas das etapas deste percurso podem ser descritas da seguinte forma:

\begin{tabular}{|c|c|c|c|c|}
\hline $\begin{array}{c}\text { Animal } \\
\text { envolvido }\end{array}$ & Cão & Pássaro & Coelho & $\begin{array}{l}\text { Tipologia de } \\
\text { Ações }\end{array}$ \\
\hline \multirow[b]{2}{*}{1} & \multirow[b]{2}{*}{$\begin{array}{l}\text { Escolha do animal na } \\
\text { ninhada - Teste de } \\
\text { Campbell }\end{array}$} & \multirow[b]{2}{*}{$\begin{array}{l}\text { Boa procedência do } \\
\text { vendedor e boa } \\
\text { aparência do animal. }\end{array}$} & \multirow[b]{2}{*}{$\begin{array}{l}\text { Boa procedência do } \\
\text { vendedor e boa } \\
\text { aparência do animal. }\end{array}$} & $\begin{array}{c}\text { Ação direta/ } \\
\text { interna/ positiva }\end{array}$ \\
\hline & & & & $\begin{array}{c}\text { Ação } \\
\text { direta/externa } \\
\text { (escolha pela } \\
\text { aparência do } \\
\text { animal). }\end{array}$ \\
\hline 2 & $\begin{array}{l}\text { Vacinação, castração, } \\
\text { desverminose e } \\
\text { remédios anti-pulgas. }\end{array}$ & $\begin{array}{c}\text { Exames (de fezes) e } \\
\text { desverminose se } \\
\text { necessário. }\end{array}$ & $\begin{array}{c}\text { Castração, } \\
\text { desverminose e } \\
\text { remédios anti-pulgas } \\
\text { (para gatos) }\end{array}$ & $\begin{array}{l}\text { Ação externa/ } \\
\text { intervencionista }\end{array}$ \\
\hline 3 & $\begin{array}{l}\text { Adestramento via } \\
\text { comandos- } \\
\text { comandos básicos } \\
\text { e/ou truques }\end{array}$ & $\begin{array}{l}\text { Adestramento-- } \\
\text { cantarolar músicas }\end{array}$ & $\begin{array}{l}\text { Socialização com } \\
\text { humanos. }\end{array}$ & $\begin{array}{c}\text { Ação } \\
\text { direta/interna }\end{array}$ \\
\hline 4 & $\begin{array}{c}\text { Socialização junto } \\
\text { aos outros animais } \\
\text { desde } 3 \text { meses de } \\
\text { idade. }\end{array}$ & $\begin{array}{l}\text { Socialização do animal } \\
\text { a partir de } 15 \text { dias. }\end{array}$ & $\begin{array}{c}\text { Socialização junto } \\
\text { aos outros animais } \\
\text { desde } 3 \text { meses de } \\
\text { idade. }\end{array}$ & $\begin{array}{l}\text { Ação exógena/ } \\
\text { participativa }\end{array}$ \\
\hline 5 & Banho e Tosa & Corte de asas & Tosa, corte de unhas & $\begin{array}{l}\text { Ação direta/ } \\
\text { deletéria/ } \\
\text { transformadora }\end{array}$ \\
\hline 6 & \begin{tabular}{|c|} 
Início das atividades \\
e incerteza de \\
sucesso
\end{tabular} & $\begin{array}{l}\text { Início das atividades } \\
\text { como terapeuta- } \\
\text { incerteza de sucesso }\end{array}$ & $\begin{array}{l}\text { Início das atividades } \\
\text { como terapeuta- } \\
\text { incerteza de sucesso }\end{array}$ & $\begin{array}{c}\text { Ação } \\
\text { participativa }\end{array}$ \\
\hline 7 & Uso da Guia & Uso da Guia & Uso da Guia & $\begin{array}{c}\text { Ação direta/ } \\
\text { intervencionista }\end{array}$ \\
\hline 8 & $\begin{array}{l}\text { Presença do animal } \\
\text { no ambiente }\end{array}$ & $\begin{array}{c}\text { Presença do animal no } \\
\text { ambiente }\end{array}$ & $\begin{array}{l}\text { Presença do animal } \\
\text { no ambiente }\end{array}$ & $\begin{array}{c}\text { Ação direta/ } \\
\text { positiva/ } \\
\text { intervencionista }\end{array}$ \\
\hline
\end{tabular}




\begin{tabular}{|c|c|c|c|c|}
\hline 9 & $\begin{array}{c}\text { Sessão terapêutica - } \\
\text { troca de ações, } \\
\text { sinais, afetos e } \\
\text { emoções }\end{array}$ & $\begin{array}{l}\text { Sessão terapêutica - } \\
\text { troca de ações, sinais, } \\
\text { afetos e emoções }\end{array}$ & $\begin{array}{l}\text { Sessão terapêutica - } \\
\text { troca de ações, } \\
\text { sinais, afetos e } \\
\text { emoções }\end{array}$ & $\begin{array}{c}\text { Ação } \\
\text { participativa }\end{array}$ \\
\hline 10 & $\begin{array}{c}\text { Final da sessão - } \\
\text { tempo estipulado } \\
\text { para o encontro ou } \\
\text { tempo do animal } \\
\text { (Sinais de cansaço e } \\
\text { /ou esquiva) }\end{array}$ & $\begin{array}{c}\text { Final da sessão - } \\
\text { tempo estipulado para } \\
\text { o encontro ou tempo } \\
\text { do animal. } \\
\text { (Sinais de cansaço e } \\
\text { /ou esquiva) }\end{array}$ & $\begin{array}{l}\text { Final da sessão - } \\
\text { tempo estipulado } \\
\text { para o encontro ou } \\
\text { tempo do animal. } \\
\text { (Sinais de cansaço e } \\
\text { /ou esquiva) }\end{array}$ & $\begin{array}{c}\text { Ação } \\
\text { participativa }\end{array}$ \\
\hline
\end{tabular}

Quadro 1: Etapas do processo de preparação do animal

As ações acima elencadas foram observadas em todas as experiências etnográficas que realizamos e discutidas com os terapeutas de zooterapia ${ }^{12}$ acerca de sua pertinência e sentido. Elas são operadas visando instaurar condições adequadas de proximidade entre o animal e os humanos.

\section{Escolha do animal}

De acordo com o que já foi sistematizado sobre a atividade da terapia com animais, pode-se considerar que, de maneira geral, o fator mais relevante na escolha daquele que tornar-se-á um terapeuta é sua personalidade. O animal escolhido deverá apresentar um temperamento adequado à atividade, excluindo-se os mais agitados para dar lugar aos que se mostram dóceis e ao mesmo tempo propositivos, capazes de interagir com humanos sem demonstrar medo ou agressividade. Assim, na busca pelo melhor animal os pássaros serão escolhidos de acordo com a espécie, isto é, a preferência por calopsitas ou papagaios está associada ao temperamento atribuído à espécie; os coelhos, considerados dóceis se socializados desde cedo, devem ser originários de bons criadores e apresentar uma pelagem exuberante, com preferência por raças de pelagem densa.

\footnotetext{
${ }^{12}$ Por ocasião Primeiro Workshop de Pet terapia, realizado em Porto Alegre, no dia 19 de outubro de 2013 e na $7^{a}$ edição do curso de Pet Terapia, realizado em Porto Alegre entre os dias 20 e 23 de outubro de 2016(https://www.facebook.com/pg/petterapeuta.com.br/photos/?tab=album\&album_id=1181978731840 316).
} 
A escolha de um cão para a zooterapia poderá ser realizadas com a ajuda do Teste de Campbell ou do TAT (Tiere als Therapi) ${ }^{13}$ baterias de testa com ações que demandam respostas do animal frente à diferentes estímulos psicológicos e sensoriais. Contudo, nos parece importante considerar o que mostrou a pesquisa de campo acerca destas previsões comportamentais advindas de testes ou protocolos pré-estabelecidos, pois nem sempre o animal reprovado mostra-se realmente inapto à atividade de terapeuta. Um exemplo disso é a cachorra Faith, da Pet Terapia, em Porto Alegre: "ela é dócil e interage com humanos com facilidade, mas ela não passou nos testes de Campbell, porque não pode ver outro cachorro que avança, vira uma fera! Mas na terapia, os pacientes podem virar ela de pernas para cima, que ela deixa" (Excerto de relato de campo, dia 11 de abril de 2012)

Estas considerações nos permitem categorizar as ações efetuadas no contexto da zooterapia, dentro da tipologia proposta por Carole Ferret ${ }^{14}$, que desenvolveu estudo na região da Sibéria em meio aos Iacoute e sua criação de cavalos. Desde este ponto de vista, as ações desenvolvidas pelo homem em direção ao animal da zooterapia podem ser consideradas como ações diretas e internas, tal como os testes utilizados para verificar o temperamento dos cães. Nestes testes, ou o humano manipula diretamente o animal, segurando-o entre mãos e posicionando-o em determinada situação hipotética de modo direto e incisivo, ou executa ações à distância em que observa a atitude do animal frente a um estimulo produzido. Estas serão, então, do tipo diretas quando o homem obriga o animal a fazer algo e serão internas quando o homem toca no animal com a mão ou com um objeto para persuadi-lo a agir (Haudricourt, 1962; Ferret, 2012, 2014).

Os pássaros devem ser adquiridos com poucos dias de vida e a partir dos quinze dias (quando ainda se alimentam de "papinhas") será inciado o processo de socialização. Sua pelagem e coloração são de extrema importância na hora da escolha e, nesse caso o animal não executa uma ação mas provoca a reação humana que através de critérios subjetivos posiciona-se a favor de um determinado animal originando nesse

\footnotetext{
${ }^{13}$ Proposto por uma instituição de zooterapia alemã, cujo um dos objetivos é "promover a ancoragem do termo 'terapia animal', na lei, para dar origem a profissão "terapeuta animal" (TAT, 2015). Endereço eletrônico da instituição: http://www.tierealstherapie.at/tat/aufgaben-und-ziele/

${ }^{14}$ Ferret, destaca que a análise das ações concretas, seja a objetos (no seu estudo, os animais), seja ao outro (homem), deve considerar que "a ação exercida sobre um ser vivo", em seu estudo o cavalo, não se exprime somente em termos de "fazer" mas também, frequentemente, em termos de "fazer fazer" pois o paciente é igualmente um agente. Nesse caso, "o sujeito humano exerce uma ação sobre um objeto animal que executará o objetivo humano" (Ferret, 2014: 22; 2012: 125).
} 
caso, uma ação do tipo direta e externa quando avalia o animal considerando sua procedência comercial. As ações do tipo externas são originárias desde a participação de um terceiro agente, neste caso os veterinários e ou criadores que adotam critérios de cativeiro e reprodução dentro de padrões éticos para com o bem-estar dos animais.

\section{Cuidados médico-veterinários}

A terapia com animais pretende se instalar como prática de cuidado dentro de um ambiente bem definido, qual seja o sistema de saúde convencional. Com isso, para que se possa trabalhar com um animal vivo dentro de um ambiente hospitalar ou voltado aos cuidados biomédicos faz -se necessário minimizar alguns inconvenientes como as alergias à pelagem ou penas ou transmissão de doenças, dos animais para os pacientes. O animal-terapeuta deverá estar limpo e com seu Atestado de Vacinas e Doenças em dia (a ser apresentado ao setor de controle de zoonoses, quando houver); apresentar um aspecto saudável, pois suas características físicas como a cor ou textura das penas ou do pelo, são atributos bastante destacados durante a terapia. $\mathrm{O}$ atestado veterinário de vacinas e doenças (aplicado a coelhos, pássaros e cães), assim como todo o trabalho de banho e tosa serão aqui considerados como ações externas e intervencionistas por serem procedimentos que visam adequar o animal às exigências do ambiente. As ações do tipo externas advém do relatório emitido por veterinários que avaliam o animal, aplicam os medicamentos e emitem este documento com uma validade determinada. Elas serão intervencionistas por serem introduzidas no corpo do animal, com vistas a garantir um estado físico ideal (assepsia). O corte das asas (pássaros) e unhas (cães, pássaros, e coelhos) são ações deletérias e transformadoras, considerando-se que suprimimos ou danificamos (de sua função) uma estrutura do corpo do animal com vistas à impedir seu funcionamento perfeito, desse modo, transformando não somente o comportamento do animal (impedir de voar, impedir de arranhar, etc.) como seu próprio corpo. Ainda nesta etapa do processo, consideramos a realização de castração (cães e coelhos) como uma ação deletéria, transformadora e contrária. De acordo com Ferret (2012), a ação do tipo deletéria e contrária visa atingir um objetivo, no caso da castração é abrandar os sinais de agitação hormonal, mas por outro lado esta ação acaba provocando a impossibilidade de reprodução daquele que é considerado um animal "bom para a atividade". 


\section{Educação para a ação}

O trabalho etnográfico nos mostrou que o animal na terapia assistida por animais passa por uma educação comportamental, associada ao ambiente em que a terapia se desenvolve, pelos quais os seres conhecem e participam da cultura. Esse processo permite socializar o animal entre diferentes tipos de pessoas e entre diferentes animais para que ele aprenda os modos de comportamento dos animais-terapeutas mais antigos na atividade. Esse procedimento é bastante aplicado pois os terapeutas trabalham com dois ou três animais na mesma sessão. Os pássaros serão socializados com outros humanos desde a mais tenra idade e deverão aprender algumas músicas conhecidas, como "atirei o pau no gato" ou hinos de equipes de futebol. Respeitados os períodos de maturação dos filhotes (15 dias), o processo de socialização se iniciará forjando-se situações de interação física entre o filhote, o terapeuta e demais pessoas que circulam no ambiente onde o filhote habita (normalmente a residência do terapeuta). Os terapeutas humanos também incitarão o animal, desde cedo, a interagir com os outros animais da casa para, mais adiante, o inserir na terapia junto aos animais mais experientes, configurando o quadro de ações dos tipos exógena e participativa.

O período de adaptação do animal servirá para que o terapeuta avalie se poderá ou não trabalhar com o novato, uma vez que suas ações de fuga, esquiva, irritação, entre outras, serão interpretadas como demonstrações de que ele não quer participar da atividade porque está cansado ou por algum outro motivo particular do animal. Para o animal que já participa da terapia, esses sinais servirão para indicar que o terapeuta deverá encerrar a sessão. A questão posta aqui é que "quase todos os animais podem ser usados para TAA", conforme relato de nossos interlocutores (Pet Terapia e TAC, Registro de campo, Porto Alegre, 2013) "mas alguns animais não podem, como os peçonhentos ou aqueles que, simplesmente, não querem" (Caderno de Campo, Porto Alegre, 2013). Assim, o comportamento do animal associado à suas necessidades e intencionalidades é uma ação do tipo participativa para o caso do animal que não se adapta à dinâmica da zooterapia ou porque não passou no teste (de Campbell) ou por que "não gosta" desta atividade. A presença do animal no contexto é uma ação do tipo direta, positiva e intervencionista, pois o humano maneja o animal até o local (diferentemente de Boris Levinson e Nise da Silveira que trabalharam com animais que 
já habitavam o contexto, como veremos em seguida).

\section{A sessão terapêutica como troca de ações}

Além de ser consenso entre os terapeutas de que é preciso e fundamental respeitar os sinais emitidos pelo animal, a etnografia demarca que o comportamento do animal associado à suas necessidades e intencionalidades pode ser categorizado, dentro da grade analítica proposta por Carole Ferret, como uma ação do tipo participativa. Desse modo, podemos observar mais detalhadamente estas categorias de ações participativa e passiva, atentando para o modo como elas foram empregadas por Carole Ferret. A ação participativa denota uma ação voluntária do animal, contribuindo para que o objetivo humano seja alcançado; a ação passiva demarca a ausência de ação humana, o que permitiria as atividades acontecerem sem que o homem intervenha na ação do animal. Estes dois tipos de ação são muito claras no contexto da zooterapia porque o humano terapeuta constantemente permite (passividade) que o animal desenvolva "trocas" com o paciente, sem intervir na interação, por um período de tempo que varia de acordo com o tempo da sessão, número de pessoas a serem atendidas e disposição dos entes para interagirem entre si.

Assim, a ação passiva do humano terapeuta que deixa o animal em "livre atuação" sem maiores estímulos para tanto15, seja durante alguns minutos, seja o tempo de uma sessão inteira, não visa outra coisa senão permitir que o animal interaja com o paciente de modo que, desde esta interação entre os dois, se produza algo que poderá ser tomado como material analítico pelo terapeuta. Durante o momento da sessão de zooterapia teremos uma série de ações que deverão ser executadas pelos animais e outras que eventualmente acontecerão sem o planejamento do terapeuta, mas atribuídas ao animal como características da espécie ou de seu temperamento.

\footnotetext{
${ }^{15}$ Lembremos que os relatos de Boris Levinson e Nise da Silveira referem-se a animais que viviam no contexto dos atendimentos clínicos, sem qualquer associação dos mesmos a qualquer tipo de terapia. As atividades de Levinson e Nise não interviam na relação do animal com o paciente, embora a tendência tenha sido de haver cada vez mais controle por parte do terapeuta-humano.
} 
Durante o trabalho de campo tivemos a oportunidade de acompanhar, sistematicamente, três espécies de animais: pássaro (calopsita e papagaio), coelho e cão; cada um deles desenvolvendo performances com diferentes respostas entre os humanos. As situações imprevistas durante a sessão, para além das ações de pular nas pernas, lamber, cantarolar ou executar qualquer ação desejável, são atos que escapam ao adestramento. Entretanto, mesmo quando essas ações características da espécie animal acontecem - voar, latir, rolar-se na terra, etc., elas são bem vindas e geram uma movimentação bastante grande entre a maioria das pessoas presentes no ambiente.

Considerando que a técnica imbricada no contexto social significa que algumas decisões técnicas foram escolhidas por razões sociais e relacionais, é interessante procurar as ações suscetíveis de produzir efeito de cuidado ou terapêutico nos humanos. Nesta perspectiva, o jogo de ações trocadas entre humanos e animais durante a sessão de zooterapia foi tomando contornos mais nítidos quando passamos a registrar a sequência de ações que era solicitada ao animal e o que isso evocava nos pacientes. Nesta perspectiva, inspirados pelo caminho metodológico apresentado por Pitrou (2014), nos perguntamos quem seriam os atores em jogo ou quais os animais que "tratam" (transformam) os outros através da mediação da ação? Do mesmo modo, nos questionamos acerca de quais seriam as ações trocadas entre esses diversos atores? $\mathrm{Ou}$ ainda, quais seriam as habilidades que eles deveriam apresentar na hora da ação. 


\begin{tabular}{|c|c|c|c|c|}
\hline $\begin{array}{l}\text { Os agentes } \\
\text { animais } \\
\text { implicados no } \\
\text { processo. }\end{array}$ & $\begin{array}{l}\text { Ações que os } \\
\text { animais devem ou } \\
\text { podem efetuar. }\end{array}$ & $\begin{array}{l}\text { Os efeitos visíveis que eles } \\
\text { produzem nos humanos } \\
\text { (pacientes). }\end{array}$ & $\begin{array}{l}\text { Ação que os animais } \\
\text { não devem efetuar }\end{array}$ & $\begin{array}{l}\text { Os efeitos visíveis que eles } \\
\text { produzem nos humanos } \\
\text { (pacientes). }\end{array}$ \\
\hline \multirow{7}{*}{ Pássaro } & $\begin{array}{l}\text { Cantar (sonidos, } \\
\text { barulhos, cânticos). }\end{array}$ & $\begin{array}{c}\text { Cantar } \\
\text { Imitar o animal } \\
\text { Conversar com o animal } \\
\text { atribuindo-lhe ideias. }\end{array}$ & Permanecer em silêncio & $\begin{array}{l}\text { Tentativas de fazer o animal } \\
\text { vocalizar; tentativas de } \\
\text { interagir com ele, conversar e } \\
\text { responder pelo animal } \\
\text { justificando o porquê dele não } \\
\text { falar. }\end{array}$ \\
\hline & $\begin{array}{l}\text { Permanecer no } \\
\text { ombro ou em } \\
\text { alguma parte do } \\
\text { corpo. }\end{array}$ & $\begin{array}{c}\text { Obriga a uma interação } \\
\text { física entre os pacientes e o } \\
\text { animal-animais sobre as } \\
\text { pernas, sobre a cama, sobre a } \\
\text { cabeça dos pacientes. }\end{array}$ & Fugir & $\begin{array}{c}\text { Buscar o animal; interessar-se } \\
\text { pelo motivo que o fez sair; } \\
\text { procurar o animal ou } \\
\text { desinteressar-se. }\end{array}$ \\
\hline & $\begin{array}{l}\text { Voar em direção à } \\
\text { alguém. }\end{array}$ & $\begin{array}{c}\text { Animação, excitação; } \\
\text { satisfação, interação com o } \\
\text { animal (Sensação de ter sido } \\
\text { escolhido). }\end{array}$ & $\begin{array}{c}\text { Voar em direção à janela } \\
\text { ou ao exterior do } \\
\text { ambiente. }\end{array}$ & $\begin{array}{l}\text { Susto, preocupação, } \\
\text { preocupação (ideia de que ele } \\
\text { quer fugir). }\end{array}$ \\
\hline & $\begin{array}{l}\text { Mordiscar, roer, } \\
\text { debicar, picar } \\
\text { levemente. }\end{array}$ & $\begin{array}{l}\text { Estabelecimento de diálogo } \\
\text { com o animal, ideia de que } \\
\text { ele faz uma massagem } \\
\text { curativa. }\end{array}$ & Bicar forte & Susto, fobia, dor e irritação. \\
\hline & $\begin{array}{l}\text { "Cafuné" - baixar a } \\
\text { cabeça para receber } \\
\text { carinho na nuca, na } \\
\text { bochecha ou no } \\
\text { pescoço. }\end{array}$ & $\begin{array}{l}\text { Acalma, tranquiliza. } \\
\text { Oferece um afago. } \\
\text { Incentiva a concentração. }\end{array}$ & Evitar o cafuné & $\begin{array}{l}\text { Tentativas de outros tipos de } \\
\text { interação, como outras formas } \\
\text { de toque ou cantar. } \\
\text { Tristeza } \\
\text { Desapontamento }\end{array}$ \\
\hline & Comer na mão & $\begin{array}{l}\text { Alegria, satisfação e } \\
\text { concentração. }\end{array}$ & Evitar a comida. & $\begin{array}{c}\text { Ideia de que ele está satisfeito } \\
\text { ou não gosta do que foi } \\
\text { oferecido. }\end{array}$ \\
\hline & Urinar ou defecar & $\begin{array}{c}\text { Se isso acontecer sobre o } \\
\text { sujeito, ele se considera com } \\
\text { sorte. Se for sobre um móvel } \\
\text { ou sobre o piso os pacientes } \\
\text { se movimentam para limpar. }\end{array}$ & $\mathrm{x}$ & $\mathrm{x}$ \\
\hline $\begin{array}{l}\text { Os agentes } \\
\text { animais } \\
\text { implicados no } \\
\text { processo. }\end{array}$ & $\begin{array}{l}\text { Ações que os } \\
\text { animais devem ou } \\
\text { podem efetuar. }\end{array}$ & $\begin{array}{l}\text { Os efeitos visíveis que eles } \\
\text { produzem nos humanos } \\
\text { (pacientes). }\end{array}$ & $\begin{array}{l}\text { Ação que os animais } \\
\text { não devem efetuar }\end{array}$ & $\begin{array}{l}\text { Os efeitos visíveis que eles } \\
\text { produzem nos humanos } \\
\text { (pacientes). }\end{array}$ \\
\hline \multirow{4}{*}{ Coelho } & $\begin{array}{l}\text { Passividade - } \\
\text { temperamento } \\
\text { tranquilo e calmo. }\end{array}$ & $\begin{array}{l}\text { Manipulação dos animais. } \\
\text { Interação física entre o } \\
\text { homem e o animal. }\end{array}$ & Agitação & $\begin{array}{c}\text { Tentativas de aproximar o } \\
\text { animal: chamar pelo seu nome, } \\
\text { sair de seu lugar para buscá-lo, } \\
\text { seguir o animal. }\end{array}$ \\
\hline & $\begin{array}{l}\text { Docilidade (Aceitar } \\
\text { a interação com os } \\
\text { humanos). }\end{array}$ & $\begin{array}{c}\text { Pentear o animal, apalpar } \\
\text { seu corpo, acariciar seu pelo. }\end{array}$ & Fugir ou esconder-se & $\begin{array}{c}\text { Insatisfação. } \\
\text { Movimentos para procurar o } \\
\text { animal ou segurá-lo. }\end{array}$ \\
\hline & Comer na mão & $\begin{array}{l}\text { Movimentos para oferecer a } \\
\text { comida ao animal. } \\
\text { Alegria, e satisfação. }\end{array}$ & $\begin{array}{c}\text { Comer as plantas do } \\
\text { jardim. }\end{array}$ & Diversão \\
\hline & $\begin{array}{c}\text { Permanecer de } \\
\text { barriga para cima } \\
\text { para ser acariciado }\end{array}$ & $\begin{array}{l}\text { Acalma, tranquiliza. Afago } \\
\text { no animal (fazer } \\
\text { 'cosquinha'). }\end{array}$ & $\begin{array}{l}\text { Chutar, arranhar ou } \\
\text { morder. }\end{array}$ & $\begin{array}{l}\text { Intimidação e curiosidade } \\
\text { sobre o porquê deste } \\
\text { comportamento ríspido. }\end{array}$ \\
\hline
\end{tabular}




\begin{tabular}{|c|c|c|c|c|}
\hline & $\begin{array}{l}\text { Exibir pelagem } \\
\text { exuberante }\end{array}$ & $\begin{array}{l}\text { Fascínio, curiosidade e } \\
\text { desejo de tocar o animal. }\end{array}$ & Arrancar seu pelo. & Preocupação e decepção. \\
\hline & $\begin{array}{c}\text { Cheirar e mexer o } \\
\text { nariz }\end{array}$ & $\begin{array}{l}\text { Diversão, interesse e } \\
\text { curiosidade. }\end{array}$ & $\begin{array}{l}\text { Cheirar e mexer o nariz } \\
\text { excessivamente }\end{array}$ & $\begin{array}{c}\text { Curiosidade } \\
\text { Sinal de que o animal está } \\
\text { estressado. }\end{array}$ \\
\hline & Cavar & $\begin{array}{c}\text { Contato com a terra e com o } \\
\text { exterior da casa ou do } \\
\text { hospital. }\end{array}$ & Fugir para cavar & $\begin{array}{l}\text { Interesse pelo animal e } \\
\text { movimentos para encontrá-lo. }\end{array}$ \\
\hline & Lamber & $\begin{array}{l}\text { Sensações táteis e troca de } \\
\text { carinho. }\end{array}$ & Morder & Susto, medo. \\
\hline & $\begin{array}{l}\text { Urinar ou defecar } \\
\text { no jardim }\end{array}$ & $\begin{array}{l}\text { Apreciação e curiosidade } \\
\text { sobre costumes do animal. }\end{array}$ & $\begin{array}{l}\text { Urinar ou defecar nas } \\
\text { pessoas }\end{array}$ & Diversão e enojamento. \\
\hline $\begin{array}{l}\text { Os agentes } \\
\text { animais } \\
\text { implicados no } \\
\text { processo. }\end{array}$ & $\begin{array}{l}\text { Ações que os } \\
\text { animais devem ou } \\
\text { podem efetuar. }\end{array}$ & $\begin{array}{l}\text { Os efeitos visíveis que eles } \\
\text { produzem nos humanos } \\
\text { (pacientes). }\end{array}$ & $\begin{array}{l}\text { Ação que os animais } \\
\text { não devem efetuar }\end{array}$ & $\begin{array}{l}\text { Os efeitos visíveis que eles } \\
\text { produzem nos humanos } \\
\text { (pacientes). }\end{array}$ \\
\hline \multirow{6}{*}{ Cão } & $\begin{array}{c}\text { Passividade } \\
\text { (Temperamento } \\
\text { tranquilo, calma). }\end{array}$ & $\begin{array}{l}\text { Manipulação dos animais. } \\
\text { Interação física entre o } \\
\text { homem e o animal. }\end{array}$ & Agitação & $\begin{array}{l}\text { Tentativas de controlar o } \\
\text { animal tocando-o, chamando-o } \\
\text { e muitas vezes deslocando-se } \\
\text { de seu lugar para trazê-lo para } \\
\text { perto. }\end{array}$ \\
\hline & $\begin{array}{l}\text { Docilidade (Aceitar } \\
\text { a interação com os } \\
\text { humanos). }\end{array}$ & $\begin{array}{c}\text { Pentear o animal, apalpar } \\
\text { seu corpo, acariciar seu pelo. }\end{array}$ & $\begin{array}{l}\text { Agressividade } \\
\text { (rosnar ou tentar } \\
\text { morder) }\end{array}$ & $\begin{array}{c}\text { Medo e susto. } \\
\text { Tentativas para acalmar o } \\
\text { animal. } \\
\text { Repulsa. }\end{array}$ \\
\hline & $\begin{array}{c}\text { Demandar, desejar } \\
\text { (Pedir colo ou saltar } \\
\text { sobre as pessoas). }\end{array}$ & $\begin{array}{c}\text { Obriga a uma interação } \\
\text { física entre os pacientes e o } \\
\text { animal (animais sobre as } \\
\text { pernas, sobre a cama, sobre a } \\
\text { cabeça dos pacientes). }\end{array}$ & $\begin{array}{l}\text { Esquivar-se, fugir, } \\
\text { negar, recusar-se, } \\
\text { desaparecer. }\end{array}$ & $\begin{array}{l}\text { Movimentos para procurar o } \\
\text { animal ou interesse pelas suas } \\
\text { necessidades. } \\
\text { Sensação de Frustração, } \\
\text { desencantamento, desgosto } \\
\text { (ele não quer brincar } \\
\text { comigo/conosco). }\end{array}$ \\
\hline & $\begin{array}{l}\text { Silêncio (ausência } \\
\text { de latidos ou } \\
\text { rosnadas). }\end{array}$ & $\begin{array}{l}\text { Conversar com o animal } \\
\text { exprimindo comentários } \\
\text { como se fossem dele. }\end{array}$ & Latir, rosnar & $\begin{array}{l}\text { Susto, medo, preocupação, } \\
\text { curiosidade. }\end{array}$ \\
\hline & Lamber & $\begin{array}{l}\text { Alegria de estar sendo } \\
\text { "beijado". }\end{array}$ & Lamber excessivamente. & Diversão ou nojo. \\
\hline & $\begin{array}{c}\text { Controlar } \\
\text { necessidades } \\
\text { fisiológicas ou fazê- } \\
\text { las em um local } \\
\text { externo ao ambiente } \\
\text { de trabalho (grama). }\end{array}$ & $\begin{array}{l}\text { Percepção do animal como } \\
\text { ser vivo instruído, } \\
\text { preparado, apto, apropriado. }\end{array}$ & $\begin{array}{l}\text { Urinar ou defecar dentre } \\
\text { os pacientes ou no } \\
\text { interior dos ambientes. }\end{array}$ & $\begin{array}{c}\text { Diversão. } \\
\text { Enojamento (inadequação, } \\
\text { desajustado, indevido, } \\
\text { improprio). }\end{array}$ \\
\hline
\end{tabular}

Quadro 2: Agentes não-humanos que participam do processo, as ações que eles devem performar e os efeitos visíveis que eles produzem nos humanos. Exemplo da categorização de ações: Coelho - Firula; pássaro: Ozzy e; cão - Faith e Phanton.;

Assim, no momento em que as ações passivas dos humanos oferecem espaço, temos como protagonistas as ações ativas dos animais que se dividem nos mais diversos movimentos trocados com os usuários. O terapeuta humano irá se abster ou 
eventualmente mediar a interação do animal, através de comentários que explorarão os frutos da relação desenvolvida com o paciente.

As ações destacadas no quadro acima se por um lado respeitam um quadro comportamental estimulado e desejado no animal, também mostram que as mesmas ações, em diferentes animais não contam com o mesmo significado entre os humanos. Um dos pré-requisitos demandados a um animal que tornar-se-á um terapeuta é que ele seja calmo o suficiente para suportar o toque e o manuseio humano, trazendo tranquilidade e segurança ao paciente com o objetivo de incitá-lo a tocar o animal. Se a manipulação e a interação física forem estabelecidas, a sensação de aprazimento, diversão e satisfação serão os motores para a continuidade da troca. Nesse momento os pássaros caminham pelo corpo dos pacientes, beliscam suas orelhas e cabelos, e se os animais estivem dispostos, poderão cantarolar algumas músicas. A vocalização dos animais, embora seja diferentemente administrada dentre as diferentes espécies (passarinhos devem cantar, mas cães não devem latir), tem um papel bastante polivalente sendo interpretado como falas antropomorfizadas dos animais até grunhidos próprios da espécie que demonstram carinho ou afago. Os grunhidos, as pequenas mordidas, cheiros, texturas de pelo, pele e penas, tipo de alimentação e costumes, dentre outras informações tornam-se características próprias de cada animal originando intervenções diferenciadas.

De acordo com os profissionais de zooterapia, torna-se fundamental conhecer o animal para também conhecer suas potencialidades e seus limites físicos e psicológicos para, então, identificar a hora de parar a sessão ou substituir o animal. Nos livrosmanuais de terapia com animais encontramos recomendações que visam assegurar o bem estar do animal da zooterapia. Desde este material deve-se proporcionar uma pausa para os animais, a cada 20 minutos de trabalho. As instruções sublinham que é fundamental ao terapeuta humano ter o máximo conhecimento possível acerca dos sinais emitidos pelos animais para colocá-los em repouso ou finalizar a sessão terapêutica. Tomemos como exemplo, alguns sinais típicos de estresse de acordo com o Delta Society (s/d: 91-92) e Chandler (2005: 60), em cães: 


\author{
Agitação (física) \\ Ofegante e salivando \\ - Pupilas dilatadas \\ - Piscar excessivamente \\ - Suando através das almofadas dos pés \\ - Inquietação, distração, agitação \\ - Falta de contato com os olhos \\ - Bocejando \\ - Cair excessivamente \\ - Vocalização excessiva \\ - Lamber os lábios \\ - Esconder-se (atrás do terapeuta) \\ - Tentando sair \\ - Necessidade de comandos repetidos \\ - Defecar ou urinar de maneira imprópria.
}

- Fugindo

Nesta atividade relacional, a troca de substâncias (subjetivas) e de ações determinará os modos como os entes se identificam ou se diferenciam perpassando por momentos de docilidade e momentos de tensão caso o animal demonstre irritação ou desconforto. Isso acontece tanto nas situação em que o animal demonstra maior docilidade ou condescendência, até os atos imprevisíveis ou nem tão agradáveis (latidos, arranhadas, pelos nas roupas, etc), porque o devir animal - nos termos de Deleuze e Guattari (1997), é parte subjacente à própria noção de que esse animalterapeuta possui sua intencionalidade. Essas ações não-humanas passam a ser circunscritas num campo de intencionalidades e tornam-se ativadores de ações humanas durante o transcorrer da sessão terapêutica. Com isso, globalmente, na sessão de zooterapia o papel do terapeuta-humano se alterna entre ações que visam promover a aproximação do animal (manejar dentro do local, propor atividades), passando por ações que pretendem deixar o animal em livre interação com o paciente, até ações ativadas pelos animais, ou que não concernem ao adestramento em regra (fugir, esconder-se, voar, etc). 
As dinâmicas do animal terapeuta: recuperação, reorganização, modificação e transformação

\section{As ações de reorganização e transformação}

Boris Levinson, o pai da terapia com animais, afirma que "the hesitais of this book is that contact with the inanimate and particular the animate world via the pets is most important to a wholesome emotional development" (Levinson, 1969: 12). Para justificar tais afirmativas, Levinson mostrou que os pacientes que viviam na enfermaria onde foi permitida a convivência com animais de estimação consumiram metade da medicação que o grupo controle da enfermaria sem animais. Para ele, o papel do animal no processo de cura pode ser localizado no lugar de "objeto transicional" no desenvolvimento infantil, conforme a perspectiva winnicotiana. O conceito de "objetos transicionais" de Winnicott (2000), refere-se aos objetos que aparentemente são artefatos macios e fofos, como os ursinhos ou cheirinhos oferecidos às crianças entre $4 \mathrm{e}$ 12 meses. De acordo com Levinson: “[...] os animais representam uma estação no meio do caminho de volta para o bem estar emocional. A necessidade de um objeto transicional é normal e indica que o inicio da 'cura' está começando, fazendo a reconciliação entre realidade e fantasia" (Levinson, 1969: 19). ${ }^{16}$

Nos anos 80, a psiquiatra Nise da Silveira descreveu as atividades de zooterapia desenvolvias no Hospital Psiquiátrico Pedro II, no Rio de Janeiro, afirmando que a parceria de um de seus pacientes com o cão Wolf, "o conduziu à uma reorganização psíquica calma e perene, pois foi ele quem significou que algumas atitudes de Wolf estariam ligadas aos seus fantasmas" (Nise da Silveira, 1982), como podemos testemunhar através do relato abaixo:

"Desde a adoção da pequena cadela Caralâmpia (1955) por um doente que frequentava uma de nossas oficinas, verifiquei as vantagens da presença de animais no hospital psiquiátrico. Sobretudo o cão reúne qualidades que o fazem muito apto a tornar-se um ponto de referencia estável no mundo externo. Nunca provoca frustrações, dá incondicional afeto sem nada pedir em troca, traz calor e alegria ao frio ambiente do hospital. Os gatos têm um modo de amar diferente. Discretos, esquivos, talvez sejam muito afins com os esquizofrênicos na sua maneira peculiar de querer bem" (Nise da Silveira 1982: 81).

\footnotetext{
${ }^{16}$ Tradução minha.
} 
As atividades descritas por Boris Levinson e Nise da Silveira, são experiências de uma prática de zooterapia quando ela ainda não existia como tal, desse modo os animais em questão despontaram como "terapeutas" de modo imprevisto, ou seja, habitavam o local como pets e foi a relação com os pacientes que chamou a atenção dos psicanalistas.

No mesmo sentido o diálogo entre uma de nossas interlocutoras e uma senhora internada no Hospital Psiquiátrico São Pedro, em Porto Alegre, durante a sessão de zooterapia, parece ilustrar um dos benefícios (atividade) que se espera ativar com o animal.

Senhora: O passarinho tá quente!

Terapeuta: E o que quer dizer ele estar quente?

S: Que ele tá cheio de vida!

T: E como é ser cheio de vida?

S: É viver a vida! Tudo que ele faz é pra viver a vida!

T- E o que será que é viver a vida pra ele?

S: É ser feliz, não reclamar, aproveitar, trabalhar no que se gosta... essas coisas.

T- E o que tu não gosta de fazer?

S: A parte do trabalho.

T- E como será o trabalho dele?

S: É bonito o trabalho dele! As crianças tudo se juntam pra ver ele. E ele diverte as crianças.

T- E o que tu faz no teu trabalho que também é legal?

S: O passarinho, por exemplo, é uma coisa que eu gosto. É uma gracinha tudo que ele tem e todo mundo ama. Mas ele, de certo, também não gostava de ficar indo nos ombros desse monte de louco. Agora a gente vê que ele gosta e se diverte até (risos). A gente agora faz bem pro passarinho.

T- O que tu acha que fez com que ele começasse a gostar de ir nos ombros de muitas pessoas.

S: Ahhh. acho que é porque ele não precisa descer na terra! Ele fica só nos nossos ombros. Ai ele não se suja! $\mathrm{E}$ os pezinhos dele ficam limpinhos.

$\mathrm{T}$ : A gente faz a nossa parte e ele faz a dele! A gente cuida dele pra ele cuidar da gente! Que bacana essa troca né?

S: Sim. É muito bacana! Agora eu acredito que eu também sou importante aqui e que eu também devo fazer coisas que as pessoas gostam com o meu trabalho!

T- Isso ai! Com certeza! E como é cuidar dele?

S: Ai é como eu estava dizendo desde lá no inicio. Eu cuido dele enchendo ele de vida. E como ele também é cheio de vida, ele me enche de vida de novo! Ai eu fico tão cheia de vida e amor que saio por ai com vontade de abraçar todo mundo! (Shutz, 2012: 17-18).

Conscientes de que não são os animais sozinhos os agentes do processo terapêutico, os profissionais imputam a reorganização psíquica de uma questão ou de um funcionamento psíquico a um ser capaz de produzir esse efeito, por meios advindos do animal que eles não conhecem totalmente. Desse modo se pede ao animal que interaja com o paciente sendo suas ações responsáveis por mudanças na percepção da 
realidade. No tratamento de fobias a animais, por exemplo, a zooterapia tem trabalhado com o que eles chamam de dessensibilização. Esse processo se baseia na ressignificação do animal através da alteração da percepção do paciente, parte do que parece ser uma relação de confiança resgatada.

Se faz necessário que consideremos o contexto do hospital ou da clinica, como o ambiente (Ingold, 2000) em que a atividade se desenvolve e ganha sentido. O animal com o status de terapeuta modifica o cotidiano dos pacientes promovendo o que, em termos biomédicos, chama-se de alteração do estado vigil. Transformar estados de percepção da realidade, de consciência e atenção, sobretudo em ambientes de longas internações, parece tomar um caráter excepcionalmente importante, conforme o relato dos cuidadores e enfermeiros dos locais visitados: "parece que eles despertam quando os animais estão aqui” (Registro de Caderno de Campo, dia 24 de maio de 2013. Informante, coordenadora do Solar Anita Garibaldi).

De modo particular, de acordo com a etnografia realizada, percebe-se que para aqueles que sofrem com problemas advindos da senilidade, alterações resultantes de traumas e doenças que ocorrem no ciclo vital- a zooterapia funciona como exercício de memória e vinculação de situações recentes com o passado do sujeito, recuperando uma capacidade gradativamente perdida devido a doenças como Alzheimer ${ }^{17}$, além de permitir a livre associação do animal com distúrbios de humor e de alimentação, delírios e pensamentos psicóticos no sentido de oferecer tranquilidade e organização psíquica. Assim, em casos onde o sujeito é privado de laços sociais, assim como os casos de autismo descritos por Boris Levinson (considerando-se as diferenças fundamentais e estruturais entre o isolamento autista e o isolamento provocado pelo manicômio), parece já bem estabelecida uma indiscutível eficácia da zooterapia.

\section{As ações de recuperação e superação}

Diversos estudos vêm sendo publicados nas últimas décadas afim de ilustrar os benefícios fisiológicos que os animais aportam. Os estudos de Friedmann et al (1990) demonstram o valor de acariciar um animal para a saúde cardíaca. Friedmann et al (1990) também postulou que as propriedades dos animais de estimação levam aos

\footnotetext{
${ }^{17} \mathrm{O}$ trabalho de Alexandre Monteiro, coordenador do Projeto Animallis, sediado no Rio de janeiro, propõe-se a tratar, através da Pet Terapia, principalmente sujeitos acometidos por Alzheimer.
} 
seguintes benefícios: (a) aptidão física melhorada, proporcionando um estímulo para o exercício; (B) diminuição da ansiedade, fornecendo uma fonte de contacto físico; e (c) diminuição da solidão, fornecendo companheirismo. Mendelson e Baggot (2007) apontaram mudanças nos níveis de oxitocina (responsável por, dentre outras coisas, provocar sensações de empatia, prazer e medo), dobrando sua concentração após interação, nos humanos e nos animais. Esse estudo também destacou o decréscimo da pressão arterial e dos níveis de cortisol.

O estudo de Alexandre Monteiro et al (2012), um dos interlocutores desta pesquisa, realizado nas dependências de uma clínica especializada em casos de Alzheimer, no Rio de Janeiro, mostrou que pacientes portadores de tal doença foram submetidos a duas baterias de avaliação neuropsicológica, espaçadas por 4 meses, para que suas funções executivas fossem identificadas quanto ao estado de funcionamento. A primeira avaliação foi feita antes do estímulo dos animais e a segunda após quatro meses de estimulação com a Terapia Assistida por Animais. Após a primeira bateria, um teste prático foi feito: uma paciente tocou piano com repertório que possuía lembrança. Por cerca de dois meses, quatro músicas foram executadas pela paciente e a mesma perseverava sem possuir consciência do fato. Após a estimulação com os animais, feita semanalmente e de forma ininterrupta, a paciente chegou a tocar 39 músicas e possuía consciência das que havia executado, não cometendo mais repetições (Monteiro et al, 2012). Os dados e resultados trazidos por Alexandre Monteiro mostram significativos sinais de melhora no que se denomina de "quadro cognitivo", principalmente em relação à memória da senhora que antes da terapia com animais tocava apenas quatro musicas e depois, passou a tocar trinta e nove.

Ainda podemos citar o relato de Joice Peruzzi, veterinária responsável pela Associação Gaúcha de Atividade e Terapia Assistida por Animais (Agata) ${ }^{18}$, em Porto Alegre. De acordo com Peruzzi, os estudos que vêm sendo realizados, desde a década de 1960, indicam que o contato do paciente com o seu animal de estimação, ou até mesmo com um animal desconhecido, pode trazer melhoras à saúde e qualidade de vida, que vão desde a redução na pressão sanguínea e nos batimentos cardíacos até a sensação de felicidade e relaxamento. O mecanismo de tratamento estaria assentado no contato com os animais que estão associados à redução de estresse (avaliado a partir dos níveis

\footnotetext{
${ }^{18}$ AGATA é a Associação Gaúcha de Atividade e Terapia Assistidas por Animais, fundada em 2011.
} 
de hormônio cortisol) e ao aumento de bem-estar relacionado à liberação de ocitocina (hormônio que protege contra o estresse) em tutores de cães, gatos e outros animais. Esses benefícios, muitas vezes, surgiriam pela simples observação de um animal ou de um aquário, por exemplo, e esta tática estaria sendo utilizada em alguns consultórios médicos e odontológicos, para ajudar a relaxar o paciente (Registro de Campo, novembro de 2013).

De um modo geral, o tipo de benefício oferecido pela interação animal, do ponto de vista físico, contribui para recuperar as habilidades motoras através de estímulos fisioterapêuticos (movimentos como acariciar, pentear, passear com o animal); melhorar as habilidades para a condução de cadeiras de rodas, andadores e etc.; recuperar o equilíbrio perdido com a idade ou doença; servir como exercício fonoaudiólogo (quando as pessoas chamam os animais ou "conversam com eles"); reduzir os riscos de problemas cardíacos e servir como tratamento respiratório, pois o contato com os animais estimularia a defesa das células e deixaria o organismo mais tolerante às bactérias, diminuindo casos de alergias e diversos problemas respiratórios.

\section{Emoções e afetos como dinâmica socializada}

Os apontamentos que precederam permitem melhor compreender as ações da sessão conectadas e coordenadas com as ações do animal. Podemos sublinhar que a questão das semelhanças e diferenças entre nós e os animais na perspectiva do comportamento emocional esbarra na difícil interrogação sobre a capacidade de um animal ter consciência sobre seus atos. Embora seja plausível considerar que os animais possuam consciência, no sentido de "dar-se-conta" de eventos no ambiente e de seus afetos, não é possível chegar a um conhecimento dos conteúdos desta consciência. As tentativas de se "olhar dentro da consciência do animal", traduzindo suas possíveis percepções em percepções humanas, só levam a metáforas.

Um olhar espontâneo dirigido aos animais pode mostrá-los semelhantes a nós, inclusive nas características subjetivas. Darwin (1889) chega a fazer as seguintes considerações: 
"I think, now been shewn that man and the higher animals, especially the Primates, have some few instincts in common. All have the same senses, intuitions, and sensations, - similar passions, affections, and emotions, even the more complex ones, such as jealousy, suspicion, emulation, gratitude, and magnanimity; they practise deceit and are revengeful; they are sometimes susceptible to ridicule, and even have a sense of humour; they feel wonder and curiosity; they possess the same faculties of imitation, attention, deliberation, choice, memory, imagination, the association of ideas, and reason, though in very different degrees." (Darwin 1889: 79).

A atribuição de características psicológicas aos animais é recorrente como recurso humano através de analogias ligadas à proximidade entre humanos e animais, mesmo que a analogia desempenhe mais um papel heurístico, dada a complexidade de se desvendar o pensamento animal (Ades, 1997; Cartmill, 2000). Defendendo a ideia de que o conhecimento animal é produto de uma construção, Ades (1997) destaca que a partir da observação de como o animal se orienta no ambiente, dos objetos que procura ou que o incomodam e dos quais foge, do modo como lida com coespecíficos, de sua comunicação, etc., chega-se a uma imagem de seu modo peculiar de ser, enquanto indivíduo e membro de uma espécie: "cria-se empatia e respeito, descobre-se como cuidar dele e, às vezes, como interagir com ele sem que a semelhança com o comportamento ou a consciência do ser humano sirva de critério primordial" (Ades, 1997: 19). De acordo com Rollin (1990), negar que os animais sintam dor, medo, ansiedade, alegria, raiva - a gama toda das emoções e paixões - além de partilhar de pelo menos algumas de nossas habilidades intelectuais, de raciocínio e cognição, é arriscarse ao desmentido do senso comum.

Entretanto, o que tem-se como consenso é que as emoções têm a característica fundamental de serem dificilmente controladas pela consciência, pois ao contrário, seriam as emoções que agiriam sobre ela. Um exemplo disso seria a expressão corporal automática e involuntária, ou o fato de ser difícil ocultá-las e disfarçá-las (Jenkins et al., 1998). A ideia de que as emoções se sobreporiam à uma consciência, como uma espécie de inevitável, se ancorou numa ideia evolutivo-biológica tendo seu ápice em trabalhos como os de Darwin. Na obra, publicada em 1872: “A expressão das emoções no homem e nos animais", Darwin estrutura as emoções em homens e animais dividindo-as em: força do hábito, princípio da antítese e , ação direta do sistema nervoso (Darwin, 2009: 36-37). O princípio dos hábitos associados úteis diz respeito a movimentos convenientes em alguns estados de espírito, que tornam-se habituais através da 
repetição; o princípio da antítese parte da proposição de um estado de espírito oposto à uma ação habitual, como pode-se ver através de situações em que o animal executa movimentos contrários ao que a intenção anterior mostrava (um cão que caminha pronto para atacar um homem e quando percebe que este homem é seu dono, imediatamente abaixa seu corpo e coloca a cauda entre as pernas, num movimento contrário); o terceiro princípio trata de comportamentos que resultam diretamente da atividade do sistema nervoso e que, portanto, são independentes da vontade (ou seja, são involuntários), por exemplo o movimento de tremor que acompanha uma sensação como o medo. Os três princípios propostos por Darwin aplicam-se à expressão de diferentes emoções que corresponderiam aos sentimentos de sofrimento, desânimo, ansiedade, medo, tristeza, alegria, ódio, entre outros.

Mas foi no século XX, marcado por pesquisas que visavam compreender o comportamento animal pelo instinto, que os etólogos Conrad Lorenz (1903-1989), Nikolaas Timbergen (1907-1988) e Karl Von Frish (1886-1982) ofereceram a fundamentação teórica do que estava se tornando a etologia, cujo marco de 1935 deu-se em decorrência da publicação da obra "O companheiro como fator no ambiente da ave", por Conrad Lorenz (Lorenz, 1995). Neste trabalho, muitas de suas idéias já se achavam delineadas como o conceito de imprinting (Prägnung), que permite explicar os movimentos ditos instintivos, numa combinação de estímulos externos e biológicos.

Jakob Von Uexküll era um biólogo que observou a vida animal desde um ponto de vista que a considerava um "sistema aberto", que ao contrario do sistema fechado interage com seu ambiente (Thure Von Uexküll, 2004). A partir dessa premissa, Uexküll (1934) desenvolveu o conceito de umwelt especifica da espécie - o segmento ambiental de um organismo, que é definido pelas capacidades específicas da espécie tanto receptoras quanto proponentes, são a sua seletividade perceptual, os seus modos peculiares de agir. Na filosofia, e seguindo o exemplo de Uexküll, Martin Heidegger (1987) estabeleceu uma distinção nítida entre o animal "captação" em sua Umwelt e a forma como o mundo é divulgado para os seres humanos. A captação do animal, na abordagem de Heidegger, também implica um sentido de abertura, na medida em que sua vida se desenvolve tal como nos termos de Jakob Von Uexküll. 
Durham $(2003)^{19}$ nos relata que as emoções nos animais são formadas por estímulos internos (inatos) ou externos (aprendidos). De acordo com seu estudo, especialmente no caso de mecanismos externos, como nos mamíferos superiores, as emoções se desenvolveriam a partir da existência de uma variação considerável nos tipos de estímulos que podem induzir uma emoção e à forma da ação que eles desencadeiam. Essa ação será selecionada em função da experiência individual ou social e, portanto, depende não apenas de condicionantes genéticos, mas também do aprendizado. A experiência influi nos mecanismos biologicamente pré-ajustados, tanto modelando o que constitui um indutor para determinadas emoções, como influindo na sua expressão. O problema desta abordagem é que caímos no mesmo problema do determinismo genético para animais e não para humanos, pois a abordagem considera que no caso dos seres humanos, a variação seria muito maior porque a cultura modelaria tanto o comportamento decorrente da emoção como o seu conhecimentoreconhecimento. Dois anos depois da publicação do artigo de Durham (2003) sobre as emoções dos chimpanzés, Eliane Rapchan e Walter Neves (2005) produzem um artigo publicado na mesma Revista de Antropologia, retificando uma série de afirmações que foram levantadas por Dhuram. Em suma, a antropóloga e o biólogo tratam de marcar as barreiras entre chimpanzés e humanos, inclusive, criticando a antropologia por ter abortado a biologia evolutiva de suas análises.

Apesar dos riscos inerentes ao antropomorfismo ${ }^{20}$ ou das projeções em pesquisas sobre o comportamento de animais não apenas é possível prever alguns comportamento dos animais, como também eles, podem prever o nosso e interpretar corretamente nossas intenções comunicando-se com os humanos. Guilherme Sá (2006), realizou trabalho etnográfico na Estação biológica de Caratinga, localizada na Fazenda Montes Claros, em Minas Gerais, observando a participação de macacos do tipo Muriqui, no estudo de questões comportamentais e hábitos alimentares destes animais. Naquele contexto, entre o marketing ecológico que evocaria uma "muriquização" (Sá, 2007) da vida humana, pela sua semelhança com a humanidade (Ingold, 1998); haveria ainda o componente da intersubjetividade que permeia as relações estabelecidas entre

\footnotetext{
${ }^{19}$ DURHAM, Eunice Ribeiro. Chimpanzés também amam: a linguagem das emoções na ordem dos primatas. Rev. Antropologia [online]. 2003, vol.46, n.1, pp. 85-154. ISSN 0034-7701.

${ }^{20}$ Usamos o termo "antropomorfismo" para fazer referência a qualquer proposta de entender o animal a partir de semelhanças - supostas ou confirmadas - com o ser humano. Não lhe é atribuído, em princípio, a conotação negativa que muitas vezes lhe é imputada, como atitude exagerada ou ingênua.
} 
pesquisadores, população local e animais. Os macacos enquanto objetos de pesquisa, dentro de um campo chamado de primatologia, entram em uma relação de "predação científica" que é justamente o processo de transformar o animal de um primata-sujeito para um primata-objeto (Sa, 2006: 119), desde a noção de purificação científica (Latour, 2001) que suscita diretamente a transubstanciação do macaco-sujeito-floresta em macaco-objeto-laboratório. Contudo, Guilherme Sá nos mostra que as variações nas formas de classificação, sobretudo no que diz respeito ao que é ser humano e nãohumano são instáveis e os processos de transformação de sujeito e objeto encontram-se enredadas em uma longa história de aproximação e distanciamento, movimento em que os muriquis não são passivos, porque as categorias cientificas são constantemente modificadas em acordo com o comportamento dos animais. Assim, Sá classificou esses coletivos em dois eixos, natureza e cultura, que se dispõem como totens de ontologias antagônicas: naturalista e culturalista (Sá, 2007: 136).

Se consideramos o animal presente no contexto urbano das grandes metrópoles e o fenômeno social quantitativamente inegável que isso representa, veremos que a convivência com animais implica o desenvolvimento de um mercado econômico em conseqüência, assim como, correlativamente a esse fenômeno, proprietários defendem seus companheiros dedicando-lhes um estatuto privilegiado e justificado, sobretudo, pelos sentimentos de paixão e amor (Arluke, 1994). Assim, os animais de companhia que, numa visão mais utilitarista são vistos como um bem ou uma propriedade, são tomados em algumas abordagens como fatores sociais na formação de identidades, membros da família para quem os humanos dedicam todo tipo de atenção e cuidados especiais, justamente pelos laços emocionais que são estabelecidos entre humanos e animais.

O que podemos afirmar sobre a zooterapia é que a representação do animal, neste contexto, se assenta na sensível percepção das necessidades e capacidades do animal, partindo do pressuposto de que a agentividade provocada pela atuação animal é responsável por aportar bem estar (quiçá a cura) aos humanos. O animal, no relato dos interlocutores, aparece como um ser pleno de potencialidades ou, como um ser-sujeito dentro de seu mundo particular. Assim, dentre as diversas representações acerca dos animais que interagimos no contexto da zooterapia, é plausível afirmarmos que lidamos com um animal singular conforme os termos de Dominique Lestel (2004). Temos, nesta relação, a legitimação de um ser vivo em seu entorno, rodeado de inúmeros signos em 
conjunto com outros signos representados e simbolizados pelos humanos, que o desinibem, que o predispõem a executar ações.

Nesse sentido, o esforço de expor o papel das emoções na prática em questão constitui um movimento de pensar os efeitos da atenção na experiência social. Com isso podemos dar lugar a uma melhor compreensão da importância metodológica das emoções no campo pesquisado e sustentar que a experiência sociocultural deve ser abordada desde a experiência das pessoas que vivem as sensações. Sabemos também, que a experiência social está vinculada a um processo de aprendizagem que nos leva a atrelar as emoções da vida pessoal e social a um esquema de pensamento. No campo da antropologia esse lugar das emoções na vida humana tem sido desenvolvido em torno de diversos fatores incluindo a insatisfação de pesquisadores com uma visão dominante que enxerga os humanos como máquinas "processadoras de informação" (Lutz, 1986). De modo geral, o paradigma dominante nos estudos da emoção nas ciências sociais tem sido baseado no materialismo de tratar as emoções como coisas materiais (pressão arterial elevada, processos hormonais e neuroquímico) e a ação de instintos que fariam parte de uma psique humana. A aproximação das emoções com o corpo é marcada por uma dicotomia que pode ser divida em dois axes, o primeiro que considera a natureza, o corpóreo, o pré-cultural das emoções; e o segundo que considera um sentimento ideal, cognitivo e cultural, chamado de 'emoções' (Lutz, 1986: 85,103).

Com um tal horizonte explicativo, consideramos que a zooterapia trata de suscitar uma experiência e na medida em que esta experiência se organiza, outros mecanismos que não têm a ver diretamente com o sujeito paciente mas como o ambiente, o terapeuta o a ação do próprio animal, vão se articulando e reorganizando espontaneamente, resultando num funcionamento ordenado que oferece sentido à prática.

\section{Intercâmbio recíproco e analogia de interioridades}

Foucault nos explica que a animalidade na idade clássica perdeu seu indício de além da vida medieval e, agora, figura-se como a loucura do homem encerrando ele em si mesmo em um estado natural. Nas palavras de Foucault (1972), a animalidade despoja o que há de humano no homem, chegando a estabelecê-lo no grau zero de sua própria natureza escapando à domesticação pelos valores e pelos símbolos humanos 
(Foucault 1972: 25-26). Embora essa animalidade estivesse inscrita na ordem do desconhecido e daquilo que escapa à compreensão humana, essa animalidade chegava a protegê-lo contra o que poderia existir de frágil, precário e doentio no e do próprio homem:

\begin{abstract}
A solidez animal da loucura, e essa espessura que ela toma emprestado do mundo cego do animal, endurece o louco contra a fome, o calor, o frio e a dor. É notório, até o final do século XVIII que os loucos podem suportar indefinidamente as misérias da existência. Inútil protegê-los: não é necessário nem cobri-los, nem aquecê-los (Foucault 1972: 151).
\end{abstract}

É bem verdade que na zooterapia, a animalidade representa esse lado obscuro da doença ou do homem, e não é por acaso que a terapia funciona especialmente nos casos de doença mental ou de perdas cognitivas. Mas a animalidade que se vê exposta através da terapia com animais não se limita ao precário ou depreciável no homem ou nos animais. Essa animalidade é também uma espécie de alegria e bem estar compartilhados entre humanos e animais, uma substância positiva que seria compartilhada entre os dois seres e que o homem tem condições de experienciar, junto deste animal. Os pacientes, ao invés de afirmarem que os animais têm emoções humanas eles assinalam que são os humanos que tem características que são presentes em todos os animais, eles acolhem o ideia de que os sentimentos e emoções presentes são uma interioridade compartilhada entre humanos e animais.

Durante a sessão terapêutica o paciente estabelece facilmente um estado de comunicação com o animal que se mantém durante todo o período da terapia pois, mesmo que o animal se afaste, quando ele retornar a interagir, o estado de comunicação permanecerá, isto é, o sujeito antes apático estará desperto para continuar a comunicarse com o animal com a mesma disposição de antes. Latour (2004: 211), afirma que "na simetria entre humanos e não-humanos mantem-se constante a série de competências e propriedades que os agentes podem permutar sobrepondo-se um ao outro", assim como podemos observar essa coreografia de troca de ações e afetos, coordenando movimentos que somente os animais podem executar com movimentos particularmente humanos. Segundo este esquema, o animal terapeuta e o humano terapeuta facilitariam a recuperação de algumas qualidades físicas e psicológicas. Na zooterapia observamos que a coisa trocada diz respeito a 'algo' que o animal oferece ao doente (amor, carinho, 
bem estar ou ganhos físicos e fisiológicos), tal como um ato de doação, de dar, ou se dar a outro, se ocupar do outro, o proteger, produzir cuidado para o outro, ou se colocar à sua disposição.

O que os dados de campo sugerem acerca da dinâmica da zooterapia é que as ações inerentes à sociabilidade que acontece entre animais e homens em contextos diversos tomam contornos de uma relação que deixa aparecer uma equivalência de posições. Isso se explica porque a sessão depende da participação ativa de todos os envolvidos para sua continuidade, tendo no terapeuta humano o disparador da atividade que deverá ser continuada pelo animal e pelo (s) paciente (s).

\section{Relações no interior da terapia com animais}

A partir da abordagem técnica da relação estabelecida entre os seres envolvidos na sessão de zooterapia, desejo contribuir com as descrições e discussões em antropologia que se preocupam em pensar instrumentos conceituais úteis para evidenciar concepções particulares de animal, presentes na sociedade contemporânea. $\mathrm{O}$ trabalho de campo priorizou a observação e descrição do saber/fazer do terapeuta de zooterapia em correspondência com um saber/fazer advindo do animal, tendo em vista não somente seu adestramento, mas também seu comportamento próprio atribuído à diferentes instâncias deste ser vivo como espécie e personalidade. No livro The Perception of the Environment: essays in livelihood, dwelling and skill, Ingold (2000) nos mostra que as habilidades estão presentes em todos os participantes de um processo agentivo que, pragmaticamente, é objetivado em um conjunto de técnicas e saberes. A noção de processo agentivo foi também discutida por Pitrou (1012) para mostrar que as ações entre os seres envolvidos num sistema deve considerar a análise dos gestos e dos discursos rituais para mostrar que, para além de sua conexão com uma ordem macrocósmica, a representação figura (miniaturização) sob uma forma abstrata atividades humanas que pretendem instaurar regimes de co-atividade entre os humanos e as entidades da natureza. 
Nesse sentido o agente não-humano implicado no processo inicia ações “causadas" por eles mesmos, não exatamente pelas leis da física ou do cosmos. O antropólogo americano Alfred $\mathrm{Gell}^{21}$, parte do principio de que os seres humanos é que seriam capazes de iniciar ações nesse sentido, admitindo que o organismo estaria distribuído em torno de uma série de objetos-artefatos inscritos por intenções originadas por humanos mas que, em seguida, estes agents passariam de agentes secundários, para agentes primários e iniciadores das ações humanas. Nem todos concordam com Gell que as ações são os efeitos de intenções primárias, pois a intencionalidade e a agência não seriam exatamente uma consequência uma da outra pois, os seres da relação não possuiriam agência em si, mas "they are rather possessed by the action... they are swept up in the generative currents of the world" (Ingold, 2011: 214).

$\mathrm{Na}$ terapia com animas os seres que ali atuam estão envolvidos na atividade de maneira consciente. De acordo com nossos informantes, os animais mudam de comportamento quando estão a caminho do trabalho "pois eles sabem que estão indo trabalhar" (Registro de campo, Projeto Animallia, Rio de Janeiro, 2012). A equivalência de posições, no momento da terapia, se manifesta em relações de similaridade, como a troca entre terapeuta e animal e refletem-se na compreensão de suas capacidades particulares, disposições e identidades, se desdobrando em ações sociais intencionais.

Desse modo, vemos na zooterapia, uma sorte de resgate da relação homemanimal dentro de um registro de confiança. Esse é um traço da técnica porque podemos situá-lo tanto entre o terapeuta e o animal, quanto entre o paciente e o animal, e entre o paciente e o terapeuta. Inversão que parte de uma espécie de confiança que os homens depositam nos animais como seres bondosos, seres que não fazem diferença entre doentes e saudáveis, negros ou brancos, heterossexuais ou homossexuais, homens, mulheres ou crianças. A confiança seria o sentimento que move a reciprocidade, sendo baseada na sensação do compartilhamento de interioridades e de uma moral perpassada por hábitos, necessidades, instintos e características do animal, o que lhe dá contornos diferenciados de uma "moral humana".

A zooterapia estabelece uma relação especifica em seu ambiente, pois a hierarquia dos animais parece não estar calcada nos graus de evolução biológica dos seres ou sobre suas características humanas necessariamente, mas principalmente sobre

\footnotetext{
${ }^{21}$ Guell, Alfred. Art and Agency. An Anthropological Theory. Oxford, Clarendon Press, 1998.
} 
os diferentes modos de troca que estão intimamente ligados às ações e sensações compartilhadas, haja vista as diferentes possibilidades que são oferecidas entre um pássaro, um cão ou um escargot. A impossibilidade de uma linguagem simbólica não exclui entre eles a expressão das sensibilidades e qualidades distribuídas diferentemente nas diversas espécies que participam da prática. Isto pode ser observado na interação entre as espécies que expressam uma predisposição a comunicarem-se com os humanos estabelecendo uma relação reflexiva dentro das possibilidades que a individualidade de cada ser pode oferecer. Conforme destaca Dominique Lestel acerca do "animal singular", "as associações poliespecíficas se tratam antes de tudo de agenciamentos carregados de sentido e de emoções entre indivíduos que pertencem a espécies diferentes, e a individualidade dos protagonistas conta mais que as espécies implicadas" 22 (Lestel, 2004: 20).

Assim, se o animal da zooterapia é um animal que por sua vontade própria aceita o trabalho de terapeuta e, se ele tem o direito de não querer trabalhar, ou se a sessão terapêutica termina quando ele demonstra sinais de cansaço, não seria plausível assumirmos que aqui há uma relação de dominação e exploração. Ela parece indicar mais uma equivalência entre o terapeuta humano o paciente e o animal, que uma exploração do animal como uma ferramenta. Os animais não parecem ser sacralizados, embora algumas vezes o sejam, como espíritos humanos reencarnados sob o olhar dos terapeutas que seguem a doutrina espirita, mas o que prevalece é a construção cada vez mais expressiva da ideia de que os animais possuem uma alma animal, com possibilidades mundanas respectivas a cada espécie, dentro de um leque de intencionalidades que podem ou não entrar em sintonia/simetria com os homens.

As sensações evocadas pelos animais têm a ver com confiança depositada (entre eles) que é desenvolvida desde uma troca comunicacional que superaria os limites das moralidades humanas. Aos que não participavam das sessões, quando questionados sobre o porque de não interagirem, respondiam que não gostavam de animais porque em algum momento de suas vidas passaram por uma situação em que a intencionalidade do animal não thes foi agradável ("o cão que atacou e mordeu o tornozelo", "o papagaio que bicou" e quase tirou um pedaço do dedo", o cavalo que com um movimento derrubou paciente). Entretanto essas ações não são endereçadas à uma pejorativa do

\footnotetext{
${ }^{22}$ Tradução minha. Grifo do autor.
} 
caráter do animal, pois o que se conclui é que os cães atacam quando se sentem ameaçados, que os pássaros bicam e que os cavalos quando cansados, São raros os que não querem ou não veem sentido na TAA, mas aqueles que não desejam participar da sessão, têm histórias que falam de uma 'negativa ação' que os faz 'perder a confiança' nos animais, e isso demonstra para essas pessoas, que os animais agem por vontade própria e que nem sempre é uma ação positiva para com o homem. Assim, em casos onde o sujeito é privado de laços sociais, assim como os casos de autismo descritos por Boris Levinson (considerando-se as diferenças fundamentais e estruturais entre o isolamento autista e o isolamento provocado pelo manicômio), parece já bem estabelecida uma indiscutível eficácia da zooterapia.

Os animais da zooterapia seriam particularmente dispostos a ajudar os humanos sem incorrer no erro de tomar as pessoas, que recebem a terapia, como deficientes sociais. Essa característica torna-se fundamental quando alivia a marca da diferença que assola o indivíduo em situação de enfermo ou residente de um espaço de saúde. Basta que o animal esteja no recinto para que os humanos se ocupem dele, considerando-se que um animal dentro de um ambiente hospitalar ainda é motivo de curiosidade, interesse ou medo. Além disso, as cores, o cheiro, a textura do pelo, das penas, o som que os animais emitem e tudo o que faz dos animais seres únicos, são uma quebra simbólica na conformação do hospital que, como destaca Foucault (1972: 456) é um espetáculo deprimente que todos encaram como o "templo da morte".

Desse modo, a maneira mais evidente de caracterizar a relação entre o animal da terapia e os humanos consiste em considerar um intercâmbio recíproco de ações e interioridades. Da mesma maneira, o processo da sessão terapêutica, que constitui o ponto culminante da participação animal, se apresenta como a condição mínima necessária para que haja uma troca entre o paciente e o animal e assim, o efeito de tal interação possa ser sentido. Como já assinalamos, a sessão terapêutica não representa tanto uma transmissão de substâncias físicas mas uma interação estabelecida em troca da reorganização ou transformação psíquica ou mental, ou recuperação ou superação de problemas neurológicos, fisiológicos e físicos. 


\section{Considerações Finais}

Se considerarmos as dinâmicas da zooterapia, é coerente afirmar que a diversidade das manifestações do que seria o beneficio oferecido pelo animal depende de uma pluralidade de ações e agentes, tanto a nível material (físico) quanto intelectual (psicológico-emocional). As análises propostas aqui mostram que o processo terapêutico da terapia por animais está engajado na percepção humana e animal, implicando modalidades de ação distintas. As causas do processo de cuidado não são imediatamente visíveis e todo o trabalho de pesquisa no campo científico é de objetivar o que parece ser inexplicável já que a comunicação entre o homem e os animais é um campo ainda bastante nebuloso.

O comportamento esperado do animal-terapeuta assemelha-se à ausência de selvageria, no que tange à agressividade, mas outras características que também estariam ligadas à animalidade, são bem vindas entre os humanos. Assim, que o tipo a animalidade construída através da zooterapia não parece ser aquela das bestas como explorou Foucault (1972), nem a marca da ausência de selvageria como propôs Ingold (1998), mas uma animalidade baseada em sinais, ações e reações próprias de um determinado ser vivo que compartilha seu mundo com o mundo humano desde diferentes processos de intercâmbio recíproco. Na zooterapia ao invés de nos perguntarmos o que os animais apresentam de humano, a pergunta inverte-se para questionarmos o que os humanos têm de animal.

O princípio do método da zooterapia como mediação animal leva em conta a capacidade do animal em evocar emoções e expressões comunicativas no ser humano através dessa ligação 'empática' entre o homem e o animal, com o reforço de laços afetivos, processos de identificação (comparação, semelhança e diferenciação) e analogia de interioridades, o que nos remete ao princípio explicativo do intercâmbio recíproco, uma vez que esse pensamento corresponde em grande parte com os dados etnográficos.

O despertar de sensações leva os pacientes a imputar um resultado positivo para sua saúde, após a sessão. Eles afirmam que os animais-terapeutas são especiais porque "fazem o bem, sem nada pedir em troca", como se a interação que ali se desenvolve fosse baseada na doação. Essa espécie de mana depositado nestes animais assenta-se no 
ponto coletivo do processo que é premissa de que o animal pode ajudar, pode oferecer benefícios à saúde humana desde a interação promovida na sessão.

\section{Referências}

ADES, César. O Morcego, Outros Bichos e a Questão da Consciência Animal. Psicologia USP, São Paulo, v. 8, n. 2, p. 129-158, 1997.

ARLUKE, Arnold. We build a better beagle: fantastic creatures in lab animal ads. In: Qualitative Sociology. Vol. 17, No. 2. 1994.

ANSONGE, J., Sudres, J.-L. La mediativo équine dans les établissements de psychiatrie infanto juvénile français. Soins psychiatrie, 277, 40-44. Elsevier Masson, 2011.

BEKOFF, M. Animal Emotions: Exploring Passionate Natures. BioScience, Vol. 50 No. 10. Oxford Journals, 2000 (10): 861-870. doi: 10.1641/0006-3568(2000)050[0861:AEEPN]2.0.CO; BLANC, Nathalie. La place de l'animal dans les politiques urbaines. Communications, [S.1.], v. 74, p. 159-175, 2003.

CARTMILL, M. Animal Consciousnes: Some Philosophical, Methodological, and Evolutionary Problems. American Zoology, 40:835-846. 2000.

CHANDLER, Cynthia K. Animal Assisted therapy in counseling. $2^{\mathrm{a}}$ ed. New York: Routledge. 2005.

COSTA NETO, E. M. As interações entre os seres humanos e os animais: a contribuição da etnozoologia. Biotemas, 20 (4): 99-110, dezembro de 2007. ISSN 0103 - 1643

, E. M. E PACHECO, J. M. Utilização medicinal de insetos no povoado de Pedra

Branca, Santa Terezinha, Bahia, Brasil. Biotemas, 18 (1): 113 - 133, 2005.

DARWIN, C. The descent of man: and selection in relation to sex. D. Appleton and Company, New York, 1889.

DARWIN, C. A expressão das emoções no homem e nos animais. Tradução: Leon de Souza Lobo Garcia. Editora: Companhia de bolso, 2009.

DELTA SOCIETY. www.petpartners.org, s/d.

DELEUZE, G. e GUATTARI, F. Mil Platôs. Capitalismo e Esquizofrenia.Tradução: Soely Rolnik. Volume 4, editora 34. São Paulo, 1997.

DEMELLO, Margo. Animals and society: an Introduction to Human- Animal Studies. New York: Columbia University Press, 2012.

DOTTI, J. Terapia e Animais. São Paulo: Noética, 2005.

DURHAM, Eunice Ribeiro. Chimpanzés também amam: a linguagem das emoções na ordem dos primatas. Revista de Antropologia. São Paulo, v. 46, n. 1, 2003. Disponível em $<$ http://www.scielo.br/scielo.php?script=sci_arttext\&pid=S0034-

77012003000100003\&lng=pt\&nrm=iso>. acessos em/22 jul. 2013. http://dx.doi.org/10.1590/S0034-77012003000100003.

FARACO C., Pizzinato A, Csordas MC, Moreira MC, Zavaschi MLS, Santos T, Oliveira VLS, Boschetti FL, Menti LM. Terapia mediada por animais e saúde mental: um programa no Centro de Atenção Psicossocial da Infância e Adolescência em Porto Alegre - TAA Parte III. Saúde Coletiva, 06 (34), pg. 231 a 236. 2009.

FERRET, Carole. Vers une anthropologie de l'action. André-Georges Haudricourt et l'efficacité technique, L'Homme n²02, p.113-140. 2012.

FERRET, Carole. Towards an anthropology of action: From pastoral techniques to modes of action, Journal of Material Culture.vol. $19 \mathrm{n}^{\circ}$ 3, p. 279-302. 2014.

FINE, Aubrey H. Handbook on Animal - Assisted Therapy. Theoretical Foudations and Guidelines for Practice. 3a Edição. London, Academic Press - Elsevier, 2010.

FOUCAULT, M. Historia da Loucura. Gallimard, 1972.

M. O nascimento da clínica. Rio de Janeiro, Forense Universitária, 1998. 
FRANKLIN, A. Animals and modern cultures. A sociology of Human-Animal in Modernity. London-California-New Delhi, Sage Publications, 1990.

FRIEDMANN, E., Locker, B. Z., e LOCKWOOD, R. Perception of animals and cardiovascular responses during verbalization with an animal present. Anthrozoös, 6(2), 115-134, 1990.

GELL, Alfred. Art and agency: an anthropological theory. Oxford: Clarendon, 1998.

GRANDGEORGE, Marine; HAUSBERGER, Martine. Human-animal relationships: from daily life to animal-assisted therapies. Ann Istitute Super Sanità, Vol. 47, n. 4: 397-408, 2011.

HALM, Margo A. The Healing Power of the Human-Animal Connection. American Journal of Critical Care, Volume 17, No. 4, Julho, 2008.

HAAR, M. Heidegger e a essência do homem. Lisboa, Instituto Piaget. 1990

HAUDRICOURT, A. Domestication des animaux, culture des plantes et traitement d'autrui.

L'Homme, V. 2, N. 1, pp. 40-50, 1962.

HEIDEGGER, M. Carta sobre o humanismo. Lisboa, Guimarães, 1987.

HEREDIA, Juan M. Etología animal, ontología y biopolitica en Jakob von Uexküll. Filosofia e História da Biologia. V. 6, n. 1, p. 69-86, 2011.

HERZOG, Harold A. Gender differences in human-animal interactions: a review. Anthrozoös, [S.1.], v. 20, n. 1, p. 7-21, 2007.

INGOLD, T. Humanidade e Animalidade. Revista Brasileira de Ciências Sociais, 28. 1998.

, T. The Perception of the Environment: essays in livelihood, dwelling and skill.

London: Routledge. 2000.

T. What is an animal. Routledge, 1994.

T. Being Alive. Routledge, 2011.

JENKINS. M. J. Compreender as emoções. Porto alegre: Instituto Jean Piaget, 1998.

JOFRE M., Leonor. Visita terapéutica de mascotas en hospitales. Revista chilena de

infectología, Santiago, v. 22, n. 3, sept. 2005. Disponible en $<$ http://www.scielo.cl/scielo.php?script=sci_arttext\&pid=S0716-

10182005000300007\&lng=es\&nrm=iso>. accedido en 17 jul. 2013. http://dx.doi.org/10.4067/S0716-10182005000300007.

JOULIAN F., Techniques du corps et traditions chimpanzières, Terrain, $\mathrm{n}^{\circ}$ 34, pp. 37-54, 2000.

LATOUR, B. A esperança de Pandora: ensaios sobre a realidade dos estudos científicos. Traduzido por Gilson César Cardoso de Sousa. Bauru, SP: EDUSC, 2001.

LATOUR, Bruno. Políticas da natureza: como fazer ciência na natureza. Traduzido por Carlos Aurélio Mota de Souza. Bauru, SP: EDUSC, 2004.

LESTEL, Dominique. As origens animais da cultura. Trad. Maria João Reis. Lisboa: Instituto Piaget, 2001.

LESTEL, D. L'Animal singulier. Seuil: Paris, 2004.

LEVINSON, Boris. Pet-Oriented Child Psychotherapy. Charles C. Thomas, publisher. Springfield, Illinois, USA. 1969.

LÉZÉ, Samuel. Décrire 1'Animal. L'Homme, 163, 2002, p. 229-234.

LORENZ, K. Os fundamentos da etologia. São Paulo: Editora da Universidade Estadual Paulista, 1995.

LUTZ, Catherine; WHITE, Geoffrey. The anthropology of emotions. Annual Reviews of Anthropology. N. 15, pp: 405-436, 1986.

MARTINS, M.F. Zooterapia ou Terapia Assistida por Animais (TAA). Revista Nosso Clínico, v.40, p.24-26, 2004.

MATUSZEK, S. Animal-facilitated Therapy in Various Patient Populations. Systematic Literature Review. Holist Nurs Pract. 24(4):187-203, 2010.

MENDELSON, J., e BAGGOT, M. Love: a chemical connection. Is there a pharmacology of love? San Francisco Medicine, 80(6), 10-15, 2007.

MERLEAU-PONTY, M. Fenomenologia da Percepção. Tradução de Reginaldo Di Piero. São Paulo: Lvraria Freitas Bastos S.A, 1971.

MICHALON, Jérôme. L'animal thérapeute: Socio-anthropologie de l'émergence du soin par le 
contact animalier. Thèse de doctorat en sociologie et anthropologie politique. École doctorale 483 Sciences sociales de l'Université de Lyon, 2011.

MONTEIRO, Alexandre M. F. O uso da Terapia Assistida por Animais para a redução de alterações de comportamento na doença de Alzheimer. Disponível em: $\mathrm{http} / / / \mathrm{www}$.centronati.com/o-uso-da-terapia-assistida-por-animais-para-a-reducao-de-alteracoesde-comportamento-na-doenca-de-alzheimer. Acesso em 10 de agosto de 2012.

NIGHTINGALE, F. Notes on Nursing. New York, NY: Dover Publications, [Originally published 1860], 1969.

PITROU, P. et Valdés, María del Carmen V. (ed.). La noción de vida en Mesoamérica. Universidad Nacional Autónoma de México, Centro de Estudios Mexicanos y Centroamericanos. Mexique, 2011.

P. Figuration des Processus Vitaux et Co-Activité dans la Sierra Mixe de Oaxaca (Mexique). L'Homme. N²02, pages 77 à 111. Éditions de l'EHESS. Paris, 2012/2.

P. Life as a process of making in the Mixe Higlands (Oaxaca, Mexico): towards a 'general pragmatics' of life. Journal of the Royal Anthropological Institute, 2014.

RAPCHAN, E.S. ; NEVES, W. A. ou Neves,W. . Chimpanzés não amam! Em defesa do significado. Revista de Antropologia (São Paulo), v. 48, p. 649-698, 2005.

ROLLIN, B.E. How the animals lost their minds: animal mentation and scientific ideology. In: BEKOFF, M.; JAMIESON, D., eds. Interpretation and explanation in the study of animal behavior. Boulder, Westview Press, 1990.

RUSSEL, N. The wild side of animal domestication. Society and Animals. V. 10 (3): 285-302, 2002.

N. The domestication of anthropology. In: CASSIDY, Rebecca; MULLIN, Molly (org.). Where the wild things are now: domestication reconsidered. New York: Berg, 2007.

SILVA e SÁ, Guilherme. Meus macacos são vocês: Um antropólogo seguindo primatólogos em campo. Anthropologicas. Recife: PPGA/UFPE, ano 9, vol 19(2), 2005.

SILVA e SÁ, Guilherme. No mesmo galho: ciência, natureza e cultura nas relações entre primatólogos e primatas. Tese de Doutorado apresentada ao Programa de Pós-Graduação em Antropologia Social, Museu Nacional, Universidade Federal do Rio de Janeiro, 2006.

SILVEIRA, Nise da. Imagens do inconsciente. Rio de Janeiro: Alhambra, 1982.

SILVEIRA, Nise da. Gatos, A Emoção de Lidar. Rio de Janeiro: Léo Christiano Editorial, 1998.

SHUTZ, Karina.Terapia Assistida por Animais aplicada à Terapia Cognitivo-Comportamental. Monografia de Especializaçao em Psicoterapia Cognitivo Comportamental, PUC, 2012.

SERPELL James. Animal-assisted interventions in historical perspective. In: FINE, Aubrey H. Handbook on Animal-Assisted Therapy: Theoretical Foundations and Guidelines for Practice. Third Edition: Academic Press is an imprint of Elsevier, 2010.

STIEGLER, Bernard. Le temps et la technique. Vol. 1: La faute d'Épiméthée. Paris, Galilée, 2001.

TEIXEIRA, Ivana. A Terapia Assistida por Animais como uma forma de associaçao: Um estudo antropologico sobre as relaçoes humano-animais na promoçao da saude humana, no Brasil. Thèse de doctorat. Universidade Federal do Rio Grande do Sul - UFRGS, Porto Alegre, Brasil. 2015.

UEXKÜLL, Jakob von. A Stroll Through the worlds of animals and men. A picture book of invisible words. International Universities Press, New York, 1934.

UEXKÜLL, Thure Von. A teoria da Umwelt de Jakob von Uexküll. Galaxia, n. 7, pp 19-48, abril de 2004.

WINNICOTT, D. "A Observação de Bebês numa Situação Padronizada”. In: Da pediatria à psicanálise. Rio de Janeiro: Imago, 2000.

Recebido em: 30/10/2016.

Aprovado em: 05/12/2016. 